rh 19 Revue d'histoire du XIXe siècle

Société d'histoire de la révolution de 1848 et des

révolutions du XIXe siècle

$16 \mid 1998$

1848. Un modèle politique à l'épreuve

\title{
Les Britanniques face au socialisme français de
}

\section{8}

\section{Fabrice Bensimon}

\section{OpenEdition}

\section{Journals}

Electronic version

URL: http://journals.openedition.org/rh19/130

DOI: $10.4000 /$ rh19.130

ISSN: 1777-5329

\section{Publisher}

La Société de 1848

\section{Printed version}

Date of publication: 1 June 1998

ISSN: 1265-1354

\section{Electronic reference}

Fabrice Bensimon, « Les Britanniques face au socialisme français de 1848 », Revue d'histoire du XIXe siècle [Online], 16 | 1998, Online since 10 September 2008, connection on 19 April 2019. URL : http:// journals.openedition.org/rh19/130 ; DOI : 10.4000/rh19.130

This text was automatically generated on 19 April 2019

Tous droits réservés 


\title{
Les Britanniques face au socialisme français de 1848
}

\author{
Fabrice Bensimon
}

\section{ABSTRACTS}

The British faced with the socialism of 1848. Great Britain, apparently spared by the 1848 revolutions, was all the same confronted with debates about the "right to work", national workshops and French socialism. Victorian society, through its notables, could not but negatively react to the utopias coming from France. However their speeches were mainly aimed at English workers who, by contrast, were to be "moderate" and "sensible". Nevertheless some groups and personalities followed the French debates on these questions with enthusiasm and high hopes: the chartists, the Irish partisans, radicals such as Stuart Mill or a socialist like Robert Owen also wanted to draw a lesson from the February Revolution in order to question the British model and make the social issue an affair of state.

La Grande-Bretagne, en apparence épargnée par les révolutions de 1848, a tout de même été confrontée à des débats et polémiques autour du " droit au travail ", des ateliers nationaux et du socialisme français. La société victorienne, en la personne de ses notables ne pouvait que réagir fort négativement aux "chimères" et autres utopies venues de France. Mais leurs discours étaient surtout destinés aux travailleurs anglais qui, par contraste, devaient faire preuve de " modération " et de "bon sens". Cependant quelques groupes et personnalités suivent avec enthousiasme et espoir les débats français sur ces questions: les chartistes, les partisans irlandais, des radicaux comme Stuart Mill ou un socialiste comme Robert Owen ont voulu eux aussi tirer les leçons de la révolution de février pour remettre en cause le modèle britannique et faire de la question sociale une affaire d'État. 
INDEX

Mots-clés: Socialisme 